\title{
In Vivo bio-distribution study of 64cu (ii)-labelled copper (ii) complexes of peptides mimics in balb/c mice-development of copper based anti- inflammatory agents
}

\begin{abstract}
Bio-distribution of $64 \mathrm{Cu}$-labelled copper(II) complexes of N,N'-di(aminoethylene)2,6-pyridinedicarbonylamine, Bis-(N,N-dimethylethyl)-2,6-pyridinedicarboxamide and N,N'-bis[2(2-pyridyl)-methyl]pyridine-2,6-pyridine-dicarboxamide was determined using Balb/c mice. Radio labelled copper (II) complexes of peptides mimics were injected in animals intravenously via tail vein and by applying on anterior dorsal side. After 1, 6 and 24 hour post-injection animals were sacrificed and organs or samples removed for measuring activity using gamma counter. Compounds accumulated in various parts of the body 1,6 and 24 hour post administration. Intravenous and dermal absorption studies showed that these compounds have 50\% retention in the body 24 hours after administration.
\end{abstract}

Keywords: rheumatoid arthritis, copper (ii), anti-inflammatory, bio-distribution, dermal absorption
Volume I Issue 5 - 2017

\author{
Sebusi Odisitse,' Graham E Jackson² \\ 'Department of Chemistry, International University of Science \\ and Technology, Botswana \\ ${ }^{2}$ Department of Chemistry, University of Cape Town, South \\ Africa \\ Correspondence: Sebusi Odisitse, Department of Chemistry \\ and Forensic Sciences, Botswana International University of \\ Science and Technology, Private Bag 16, Palapye, Botswana, Tel \\ +267493 1583, Fax +267490 0102, \\ Email odisitses@biust.ac.bw
}

Received: September 26, 2017 | Published: October 16, 2017

\section{Introduction}

Rheumatoid arthritis (RA) is a chronic, systemic, inflammatory, debilitating autoimmune disease for which there is no cure. ${ }^{1,2}$ However, the symptoms and progression of the disease can be treated using immunosuppressive and anti-inflammatory drugs. ${ }^{3,4}$ The inflammatory process targets primarily the synovial tissue, causing inflammation and subsequent joint damage. Reports in the literature suggest that there is a localized deficiency of copper associated with RA. ${ }^{5}$ Elevation of copper (II) complex species concentration in the plasma and synovial fluids of RA patients is well reported. ${ }^{5-7}$ In vivo, copper exists in three different forms: irreversibly bound to metalloproteins like ceruloplasmin, reversibly bound to plasma proteins like serum albumin and as low molecular mass $(1 \mathrm{~mm})$ complexes. The latter fraction constitutes the smallest fraction in plasma and the target of this work is to elevate this fraction by either exogenous administration or by mobilizing endogenous copper may be of beneficial.

With this in mind, we have embarked on a programme with the aim of designing compounds that will complex copper and increase its bioavailability and at the same time not disrupt the homeostasis of other endogenous metal ions. The compound must form stable, lipophilic, copper complex capable of surviving in vivo to exert its therapeutic potential at the possible sites of inflammation. In this study we have synthesized compounds which possess some common properties as those of nitrogen containing bio-functional molecules such as oligopeptides. ${ }^{8}$ The benzyl and pyridyl groups in these compounds are mainly found in most of the non-steroidal anti-inflammatory drugs (NSAIDs) and $\mathrm{Cu}$ (II)-NSAIDs complexes are reported to be more effective than their parent compounds. ${ }^{9}$ We study the bio-distribution of these compounds in mice using ${ }^{64} \mathrm{Cu}$ (II) as a radiotracer. This allows the determination of the changed bioavailability and efficacy of these agents in transporting $\mathrm{Cu}$ (II) through the body to possible sites of inflammation as well as determining the compound's in vivo stability. Administration of the agents was performed intravenously through the tail vein and percutaneously on the anterior dorsal side of the mice.

\section{Materials and methods}

\section{Animals}

Bio-distribution studies on mice were approved by the Research Animals Ethics Committee of the University of Cape Town (permission number 005/039). The procedures for carrying out experiments were done in compliance with the guidelines set by the University of Cape Town Research Animals Ethics Committee. Female Balb/c mice of age 7-8 weeks weighing 19-23 grams supplied by Animal Unit of the University of Cape Town were used in these experiments and were kept in polycarbonate cages and allowed food and water ad libitum.

\section{Radionuclide ${ }^{64} \mathrm{CuCl}_{2}$ and Peptides mimics}

The radioactive ${ }^{64} \mathrm{CuCl}_{2}$ was supplied by South African Nuclear Energy Cooperation (Ltd). The authority to possess and use radioactive nuclide ${ }^{64} \mathrm{Cu}$ (II) (half-life $=12.7$ hours) was granted by the University of Cape Town's radiation protection and health safety committee in conjunction with Department of Health (authority number $33 / 01 / 0327) .{ }^{64} \mathrm{Cu}$ was prepared by neutron irradiation of $1.7-$ $2.5 \mathrm{mg}$ copper (II) oxide (99.9999\%, Aldrich Chem. Co., WI, USA) for 24 hours at a thermal neutron flux of $1.0 \times 1014$ neutrons $\mathrm{cm}^{-2} \mathrm{~s}^{-1}$ in a Safari-1 Research Reactor. The targets were dissolved in $1.0 \mathrm{ml}, 1.0 \mathrm{M}$ $\mathrm{HCl}$ and diluted to $3.0 \mathrm{ml}$ with $1.0 \mathrm{M} \mathrm{HCl}$. Typical specific activities of $98 \%$ radioactively pure ${ }^{64} \mathrm{Cu}$ of $\sim 600 \mathrm{MBq} \mathrm{mg}-1$ target material were obtained. Caution: ${ }^{64} \mathrm{Cu}$ decays by positrons emissions, which annihilate to produce tissue penetrating high energy $\gamma$-radiation. Therefore, it is advisable to use low activity of ${ }^{64} \mathrm{Cu}$ and perform all experiments behind lead bricks inside a fume cupboard. 
Synthesis of peptides mimics (Figure 1) in this study has been reported in our previous studies. ${ }^{10,11} \mathrm{Cu}(\mathrm{II})$ complexes of N,N'-di(aminoethylene)-2,6-pyridinedicarbonylamine (L1), Bis(N,N-dimethylethyl)-2,6-pyridine-dicarboxamide (L2) and N,N'bis[2(2-pyridyl)-methyl]pyridine-2,6-pyridine-dicarboxamide (L3) characterized from our previous studies, were prepared in sterile saline solution at $\mathrm{pH} 7.4 .^{10,11}$ These solutions were spiked with 10$14 \mathrm{~m} \mathrm{Ci}{ }^{64} \mathrm{CuCl}_{2}$ (aq). The structures of the possible formed species in solution at $\mathrm{pH} 7.4$ are shown in Figure 2.<smiles>NCCNC(=O)c1cccc(C(=O)NCCN)n1</smiles>

L1<smiles>CN(C)CCNC(=O)c1cccc(C(=O)NCCN(C)C)n1</smiles>

L2

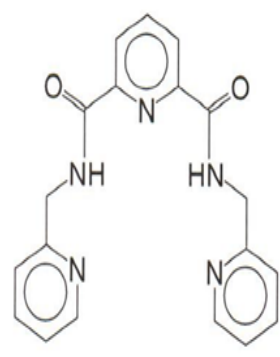

L3
Figure I Schematic structures of ligands (L) studied in the conformation they would adopt when coordinated to a metal ion.

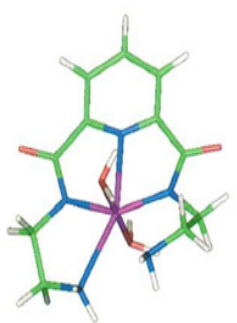

$\mathrm{Cu}(I I)-\mathrm{L} 1$

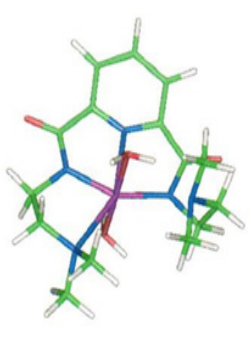

$\mathrm{Cu}(\mathrm{II})-\mathrm{L} 2$

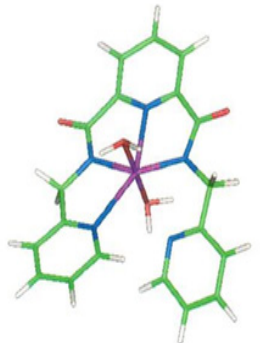

$\mathrm{Cu}(\mathrm{II}) \mathrm{L} \mathrm{L} 3$
Figure 2 Structures of possible radio labelled copper (II) complexes formed in solution at physiological $\mathrm{pH} 7.4$.

\section{Bio-distribution by intravenous administration}

The experimental approach adopted for these experiments was similar to the approach of several researchers in the field of nuclear medicine. ${ }^{12-14} \mathrm{~A}$ total of 48 female Balb/c mice were housed in groups of three (3) mice per cage and were given food and water ad libitum during the investigation period. These groups were injected with $0.2 \mathrm{~cm}^{3}$ of $5 \mu \mathrm{Ci}\left[{ }^{64} \mathrm{Cu}\right] \mathrm{Cu}(\mathrm{II})-\mathrm{L}$ solutions via tail vein and another group was injected with ${ }^{64} \mathrm{CuCl}_{2}$ (aq) as a control experiment. Since the body is a dynamic system, the bio-distribution was measured as a function of time. At 1, 6 and 24 hour post-injection time points, groups of mice (three at a time) were anaesthetized by carbon dioxide inhalation and aliquots of blood taken from the heart. Various samples were removed, rinsed with $\mathrm{NaCl}(0.9 \%)$, dried and then weighed.

\section{Bio-distribution by percutaneous administration}

Dermal absorption experiments were performed by applying $0.2 \mathrm{~cm}^{3}$ of $5 \mu \mathrm{Ci}$ solutions to an enclosed portion of skin on the anterior dorsal side of the female Balb/c mice. The application site was prepared 15 hours prior to dosing by clipping an area of approximately $2 \times 2 \mathrm{~cm}$ on the dorsal side of the test animals. The animals were anaesthetized with a saline solution of ketamine/xylazine following clipping and a small tubing ring $(1.2 \mathrm{~cm}$ diameter and $0.5 \mathrm{~cm}$ height $)$ was fixed to their backs using cyanoacrylate adhesive. At 24 hour post-dosing, groups of mice (four at a time) were anaesthetized by carbon dioxide inhalation and the procedure for removing samples followed that of the intravenous bio-distribution experiments.

\section{Analytical measurements}

The radioactivity in all samples including controls as well as the collected urine were counted using a Minaxi Auto-gamma 5000 Series counter with the window set at $340-540 \mathrm{KeV}$. All readings were corrected for background noise by subtracting the activity of an empty sample bottle and also adjusted to activity at time zero according to the half-life of ${ }^{64} \mathrm{Cu}$ (II) using exponential decay law. The percentages of radio-activity dose per organ and/or per gram (g) tissue were computed from the mean organ weights after correction for radioactivity decay.

\section{Results and discussion}

Bio-distribution in female Balb/c mice by intravenous and dermal absorption was measured as a function of time using ${ }^{64} \mathrm{Cu}$ (II) as a tracer. Table $1 \& 2$ Shows the bio-distribution of ${ }^{64} \mathrm{Cu}$-labelled $\mathrm{Cu}$ (II)-L1, $\mathrm{Cu}$ (II)-L2, $\mathrm{Cu}$ (II)-L3 and $\mathrm{CuCl}_{2}$ at 1, 6 and 24 hours postintravenous injection. The results show an initial rapid clearance from the blood circulation and rapid uptake by the liver for all complexes. The high uptake by the liver is expected because copper storage and metabolism occurs in this organ. The $\left[{ }^{64} \mathrm{Cu}\right] \mathrm{CuCl}_{2}$ used a control, was rapidly excreted via hepatobiliary and renal routes. All the compounds showed much longer biological half-life than those studied by Jackson and co-workers. ${ }^{12,15}$ About $50 \%$ of the activity was retained in the body after 24 hours for these compounds compared to about $20 \%$ of the $\left[{ }^{64} \mathrm{Cu}\right] \mathrm{CuCl}_{2}$ control. This activity accumulation and retention over 24 hours in the body is of interest and merits evaluation of these copper chelating agents for possible design of metal-based anti-inflammatory agents as well as use in chemotherapy and diagnosis. The question of toxicity does arise, as $\mathrm{Cu}$ (II) is known to be toxic. However, previous studies, using non-radioactive copper, showed complexed copper complexes to have much lower toxicity than free copper. ${ }^{15-18}$

Anderson and co-workers have investigated thermodynamically and kinetically stable ${ }^{64} \mathrm{Cu}$-lebelled macrocyclic complexes with different formal charges as bio-functional chelators. ${ }^{16,17}$ All the complexes were observed to be rapidly cleared from blood circulation and positively charged complexes had higher uptake and slow clearance. In this study, it is interesting to note that the carcass activity is higher after 24 hours than 6 hours. This is because, after the rapid clearance from the blood by the liver, it is slowly released and redistributed into other tissues. For the control, most of the copper is excreted in the urine while for L1, L2 and L3, there is substantial amount in the intestines and retention in the liver.

Of all the various classical ways of drug administration, percutaneous absorption is the preferred route. Therefore, biodistribution studies were also performed using dermal absorption. The results in Table 2 show that a significant amount of activity is absorbed within 24 hours. However, of note here is that the same biodistribution as intravenous injection is not obtained as shown in Table 3. This is because of the use of a different route of administration. Of interest is that more activity is retained in the body while less activity is excreted in the urine. 
Table I Bio-distribution in bulb/c mice [\% dose per organ and per gram tissue (in brackets)] of $\left[{ }^{64} \mathrm{Cu}\right] \mathrm{Cu}(\mathrm{II})-\mathrm{L}$ agents following intravenous injection via the tail vein (mean \pm std.dev, $n=3$ ) after I, 6 and 24 hour post-injection

\begin{tabular}{|c|c|c|c|c|c|}
\hline \multirow[t]{2}{*}{ Organ } & \multirow[t]{2}{*}{ Time/h } & \multicolumn{4}{|c|}{$\%$ Dose per organ (\% Dose per gram tissue) } \\
\hline & & {$\left[{ }^{64} \mathrm{Cu}\right] \mathrm{Cu}(\mathrm{II})-\mathrm{LI}$} & {$\left[{ }^{64} \mathrm{Cu}\right] \mathrm{Cu}(\mathrm{II})-\mathrm{L} 2$} & {$\left[{ }^{64} \mathrm{Cu}\right] \mathrm{Cu}(\mathrm{II})-\mathrm{L} 3$} & {$\left[{ }^{6} \mathrm{Cu}\right] \mathrm{CuCl}_{2}$} \\
\hline \multirow[t]{6}{*}{ Blood } & I & $1.61 \pm 0.15$ & $1.39 \pm 0.20$ & $2.89 \pm 0.56$ & $0.80 \pm 0.08$ \\
\hline & & $(1.31 \pm 0.07)$ & $(1.04 \pm 0.18)$ & $(2.37 \pm 0.38)$ & $(0.63 \pm 0.07)$ \\
\hline & 6 & $1.0 \pm 0.1$ & $0.89 \pm 0.05$ & $1.22 \pm 0.33$ & $0.8 \pm 0.2$ \\
\hline & & $(0.76 \pm 0.10)$ & $(0.73 \pm 0.03)$ & $(1.02 \pm 0.35)$ & $(0.62 \pm 0.17)$ \\
\hline & 24 & $2.8 \pm 0.8$ & $2.2 \pm 0.2$ & $2.08 \pm 0.20$ & $0.9 \pm 0.2$ \\
\hline & & $(2.12 \pm 0.54)$ & $(1.77 \pm 0.11)$ & $(1.62 \pm 0.27)$ & $(0.7 I \pm 0.22)$ \\
\hline \multirow[t]{6}{*}{ Carcass } & I & $34.02 \pm 4.68$ & $36.04 \pm 9.95$ & $31.32 \pm 3.78$ & $31.51 \pm 7.29$ \\
\hline & & $(2.23 \pm 0.35)$ & $(2.14 \pm 0.71)$ & $(2.02 \pm 0.10)$ & $(2.00 \pm 0.43)$ \\
\hline & 6 & $8 \pm 10.6$ & $7.4 \pm 0.8$ & $7.08 \pm 1.54$ & $8 \pm 2$ \\
\hline & & $(6 \pm 0.09)$ & $(0.63 \pm 0.05)$ & $(0.60 \pm 0.09)$ & $(0.63 \pm 0.17)$ \\
\hline & 24 & $16 \pm 4$ & $19 \pm 4$ & $12.02 \pm 0.29$ & $11 \pm 2$ \\
\hline & & $(I .24 \pm 0.21)$ & $(1.40 \pm 0.17$ & $(1.11 \pm 0.17)$ & $(0.95 \pm 0.20)$ \\
\hline \multirow[t]{6}{*}{ Head } & I & $2.05 \pm 0.02$ & $3.20 \pm 0.54$ & $3.63 \pm 0.35$ & $2.54 \pm 0.17$ \\
\hline & & $(0.69 \pm 0.06)$ & $(1.06 \pm 0.18)$ & $(1.30 \pm 0.11)$ & $(0.78 \pm 0.01)$ \\
\hline & 6 & $1.94 \pm 0.08$ & $2.0 \pm 0.2$ & $6.94 \pm 0.79$ & $1.94 \pm 0.04$ \\
\hline & & $(0.66 \pm 0.04)$ & $(0.65 \pm 0.04$ & $(0.55 \pm 0.05)$ & $(0.59 \pm 0.02)$ \\
\hline & 24 & $4 \pm|\quad| .4$ & $4.7 \pm 0.3$ & $3.40 \pm 0.11$ & $8 \pm 3$ \\
\hline & & $(6 \pm 0.35)$ & $(1.44 \pm 0.14)$ & $(I . I I \pm 0 . I I)$ & $(2.60 \pm 1.09)$ \\
\hline \multirow[t]{4}{*}{ Heart } & 6 & $0.28 \pm 0.04$ & $0.20 \pm 0.03$ & $0.2 I \pm 0.02$ & $0.19 \pm 0.02$ \\
\hline & & $(1.84 \pm 0.40)$ & $(1.70 \pm 0.22)$ & $(1.80 \pm 0.15)$ & $(1.56 \pm 0.15)$ \\
\hline & 24 & $0.6 \pm 0.2$ & $0.6 \pm 0.1$ & $0.46 \pm 0.05$ & $0.2 I \pm 0.07$ \\
\hline & & $(5.62 \pm 0.46)$ & $(3.99 \pm 0.26)$ & $(3.99 \pm 0.26)$ & $(1.73 \pm 0.43)$ \\
\hline \multirow[t]{4}{*}{ Intestines } & 6 & $15 \pm 2$ & $15 \pm 2$ & $12.23 \pm 0.99$ & $22 \pm 3$ \\
\hline & & $(3.93 \pm 0.80)$ & $(7.24 \pm 0.16)$ & $(4.2 I \pm 0.73)$ & $(8.14 \pm I .12)$ \\
\hline & 24 & $24 \pm 4$ & $26 \pm 4$ & $30.25 \pm 4.18$ & $12 \pm 7$ \\
\hline & & $(8.27 \pm 0.89)$ & $(8.79 \pm 1.00)$ & $(9.18 \pm 2.13)$ & $(3.95 \pm 1.86)$ \\
\hline \multirow[t]{4}{*}{ Kidney } & 6 & $1.2 \pm 0.2$ & $1.15 \pm 0.08$ & $2.21 \pm 0.90$ & $1.0 \pm 0.2$ \\
\hline & & $(3.03 \pm 0.33)$ & $(3.32 \pm 0.19)$ & $(6.33 \pm 0.90)$ & $(3.09 \pm 0.4 I)$ \\
\hline & 24 & $2.8 \pm 0.6$ & $2.7 \pm 0.3$ & $2.3 I \pm 0.34$ & $1.0 \pm 0.4$ \\
\hline & & $(8.75 \pm 0.62)$ & $(7.6 I \pm 0.59)$ & $(6.16 \pm 0.44)$ & $(3.03 \pm 1.03)$ \\
\hline \multirow[t]{6}{*}{ Liver } & I & $60.03 \pm 5.18$ & $58.18 \pm 6.00$ & $59.53 \pm 2.69$ & $61.57 \pm 6.91$ \\
\hline & & $(57.37 \pm 9.66)$ & $(50.67 \pm 2.30)$ & $(52.8 I \pm 4.38)$ & $(52.94 \pm 6.18)$ \\
\hline & 6 & $70.7 \pm 0.8$ & $67 \pm 1$ & $64.31 \pm 2.89$ & $64 \pm 5$ \\
\hline & & $(54.59 \pm 8.15)$ & $(66.54 \pm 9.31)$ & $(58.52 \pm 3.70)$ & $(56.20 \pm 0.45)$ \\
\hline & 24 & $40 \pm 5$ & $39 \pm 7$ & $35.56 \pm 9.26$ & $11 \pm 7$ \\
\hline & & $(37.77 \pm 5.18)$ & $(31.00 \pm 6.13)$ & $(4.79 \pm 0.85)$ & $(11.32 \pm 0.64)$ \\
\hline \multirow[t]{3}{*}{ Lung } & 6 & $0.3 \pm 0.3$ & $0.5 \pm 0.2$ & $0.45 \pm 0.14$ & $0.53 \pm 0.08$ \\
\hline & & $(2.24 \pm 0.67)$ & $(3.22 \pm 0.72)$ & $(4.01 \pm 0.59)$ & $(1.85 \pm 0.25)$ \\
\hline & 24 & $1.3 \pm 0.6$ & $1.3 \pm 0.1$ & $1.00 \pm 0.03$ & $0.4 \pm 0.2$ \\
\hline
\end{tabular}




\begin{tabular}{|c|c|c|c|c|c|}
\hline \multirow[t]{2}{*}{ Organ } & \multirow[t]{2}{*}{ Time/h } & \multicolumn{4}{|c|}{ \% Dose per organ (\% Dose per gram tissue) } \\
\hline & & {$\left[{ }^{64} \mathrm{Cu}\right] \mathrm{Cu}(\mathrm{II})-\mathrm{LI}$} & {$\left[{ }^{64} \mathrm{Cu}\right] \mathrm{Cu}(\mathrm{II})-\mathrm{L} 2$} & {$\left[{ }^{64} \mathrm{Cu}\right] \mathrm{Cu}(\mathrm{II})-\mathrm{L} 3$} & {$\left[{ }^{64} \mathrm{Cu}\right] \mathrm{CuCl}_{2}$} \\
\hline & & $(8.90 \pm 0.77)$ & $(4.79 \pm 0.85)$ & $(6.23 \pm 0.45)$ & $(2.27 \pm 0.34)$ \\
\hline \multirow[t]{4}{*}{ Muscle } & 6 & $0.05 \pm 0.01$ & $0.05 \pm 0.02$ & $0.06 \pm 0.03$ & $0.06 \pm 0.04$ \\
\hline & & $(0.23 \pm 0.04)$ & $(0.44 \pm 0.04)$ & $(0.43 \pm 0.17)$ & $(0.42 \pm 0.13)$ \\
\hline & 24 & $0.09 \pm 0.01$ & $0.14 \pm 0.06$ & $0.12 \pm 0.03$ & $0.04 \pm 0.03$ \\
\hline & & $(1.05 \pm 0.40)$ & $(1.02 \pm 0.14)$ & $(0.79 \pm 0.22)$ & $(0.25 \pm 0.10)$ \\
\hline \multirow[t]{4}{*}{ Spleen } & 6 & $0.17 \pm 0.06$ & $0.23 \pm 0.01$ & $0.14 \pm 0.03$ & $0.23 \pm 0.04$ \\
\hline & & $(0.3 \mid \pm 0.13)$ & $(2.03 \pm 0.31)$ & $(2.02 \pm 0.5 \mathrm{I})$ & $(1.73 \pm 0.13)$ \\
\hline & 24 & $0.5 \pm 0.2$ & $0.7 \pm 0.2$ & $0.30 \pm 0.13$ & $0.12 \pm 0.02$ \\
\hline & & $(9.18 \pm 0.53)$ & $(5.22 \pm 0.90)$ & $(2.92 \pm 0.93)$ & $(1.32 \pm 0.11)$ \\
\hline \multirow[t]{3}{*}{ Urine } & 1 & $2.30 \pm 0.40$ & $1.18 \pm 0.52$ & $2.64 \pm 0.70$ & $3.58 \pm 0.48$ \\
\hline & 6 & $1.7 \pm 0.2$ & $0.9 \pm 0.5$ & $|0.48 \pm 2.3|$ & $2 \pm 1$ \\
\hline & 24 & $7 \pm 1$ & $3.6 \pm 0.9$ & $12.52 \pm 4.42$ & $55 \pm 9$ \\
\hline
\end{tabular}

Table $2 \%$ Dose unabsorbed and \% dose absorbed for the dermal absorption study of $\left[{ }^{64} \mathrm{Cu}\right] \mathrm{Cu}$ (II) complexes of LI, L2 and L3 24 hour post-dosing in bulb/c mice

\begin{tabular}{|c|c|c|c|c|c|}
\hline \multicolumn{6}{|c|}{ \%Dose unabsorbed (ring + enclosed skin) and } \\
\hline \multicolumn{6}{|c|}{ \% Dose absorbed (body + urine) in brackets for per mouse 24 hour post-dosing } \\
\hline & Mouse I & Mouse 2 & Mouse 3 & Mouse 4 & Average \% dose(per mouse) \\
\hline \multirow[t]{2}{*}[{}^{64}\mathrm{Cu}]{$\mathrm{Cu}(\mathrm{II})-\mathrm{LI}$} & 95.72 & 77.77 & 97.008 & 85.15 & 88.21 \\
\hline & $(-4.28)$ & $(-22.23)$ & $(3.00)$ & $(-14.85)$ & $(-11.09)$ \\
\hline \multirow[t]{2}{*}[{}^{64}\mathrm{Cu}]{$\mathrm{Cu}(\mathrm{II})-\mathrm{L} 2$} & 95.06 & 62.89 & 89.93 & 82.75 & 82.66 \\
\hline & $(-4.94)$ & $(-37.11)$ & $(-10.07)$ & $(-17.25)$ & $(-17.34)$ \\
\hline \multirow[t]{2}{*}[{}^{64}\mathrm{Cu}]{$\mathrm{Cu}(\mathrm{II})-\mathrm{L} 3$} & 82.32 & 64.05 & 55.42 & 79.94 & 70.43 \\
\hline & $(-17.68)$ & $(-35.95)$ & $(-44.58)$ & $(-20.06)$ & $(-29.57)$ \\
\hline \multirow[t]{2}{*}[{}^{64}\mathrm{Cu}]{$\mathrm{CuCl}_{2}$} & 77.57 & 87.55 & 95.66 & 73.63 & 83.6 \\
\hline & $(-22.43)$ & $(-12.45)$ & $(-4.44)$ & $(-26.27)$ & $(-16.4)$ \\
\hline
\end{tabular}

Table 3 Bio-distribution in bulb/c mice [\% dose per organ and per gram tissue (in brackets)] of $\left.{ }^{64} \mathrm{Cu}\right] \mathrm{Cu}(\mathrm{II})-\mathrm{L}$ agents (mean \pm std.dev. $\left.n=4\right)$ after 24 hours of dermal absorption

\begin{tabular}{lllll}
\hline \multicolumn{5}{l}{$\%$ Dose per organ $(\%$ Dose per gram tissue) } \\
\hline Organ & {$\left[{ }^{64} \mathrm{Cu}\right] \mathrm{Cu}(\mathrm{II})-\mathrm{LI}$} & {$\left[{ }^{64} \mathrm{Cu}\right] \mathrm{Cu}(\mathrm{II})-\mathrm{L2}$} & {$\left[{ }^{64} \mathrm{Cu}\right] \mathrm{Cu}(\mathrm{II})-\mathrm{L3}$} & {$\left[{ }^{64} \mathrm{Cu}\right] \mathrm{CuCl}_{2}$} \\
\hline Blood & $0.53 \pm 0.05$ & $2.0 \pm 0.1$ & $0.34 \pm 0.02$ & $2.25 \pm 0.08$ \\
& $(0.45 \pm 0.26)$ & $(1.28 \pm 0.32)$ & $(0.32 \pm .10)$ & $(1.50 \pm 0.23)$ \\
Carcass & $23 \pm \mathrm{I}$ & $28 \pm 13$ & $9.69 \pm 5.72$ & $14 \pm 10$ \\
& $(0.22 \pm 0.1 \mathrm{I})$ & $(1.84 \pm 0.8 \mathrm{I})$ & $(0.92 \pm 0.56)$ & $(0.89 \pm 0.59)$ \\
Head & $9 \pm 8$ & $8 \pm 3$ & $18.09 \pm 8.30$ & $3.3 \pm 0.7$ \\
& $(3.35 \pm 2.97)$ & $(2.29 \pm 0.79)$ & $(6.90 \pm 3.16)$ & $(1.02 \pm 0.20)$ \\
Heart & $0.11 \pm 0.02$ & $0.37 \pm 0.02$ & $0.07 \pm 0.01$ & $0.37 \pm 0.07$ \\
& $(1.14 \pm 0.22)$ & $(2.01 \pm 0.1 \mathrm{I})$ & $(0.62 \pm 0.12)$ & $(2.10 \pm 0.43)$ \\
Intestines & $13 \pm 5$ & $12 \pm 2$ & $15.99 \pm 6.24$ & $21 \pm 3$ \\
& $(4.18 \pm 1.73)$ & $(3.21 \pm 0.52)$ & $(6.47 \pm 2.47)$ & $(6.27 \pm 0.70)$ \\
Kidney & $0.35 \pm 0.05$ & $1.8 \pm 0.1$ & $0.30 \pm 0.03$ & $1.7 \pm 0.3$ \\
\hline
\end{tabular}


Table Continued.

\begin{tabular}{|c|c|c|c|c|}
\hline \multirow[b]{2}{*}{ Organ } & \multicolumn{4}{|c|}{ \% Dose per organ (\% Dose per gram tissue) } \\
\hline & {$\left[{ }^{64} \mathrm{Cu}\right] \mathrm{Cu}(\mathrm{II})-\mathrm{LI}$} & {$\left[{ }^{64} \mathrm{Cu}\right] \mathrm{Cu}(\mathrm{II})-\mathrm{L} 2$} & {$\left[{ }^{64} \mathrm{Cu}\right] \mathrm{Cu}(\mathrm{II})-\mathrm{L} 3$} & {$\left[{ }^{64} \mathrm{Cu}\right] \mathrm{CuCl}_{2}$} \\
\hline & $(1.02 \pm 0.15)$ & $(3.5 I \pm 0 . I)$ & $(0.94 \pm 0.11)$ & $(3.61 \pm 0.63)$ \\
\hline \multirow[t]{2}{*}{ Liver } & $17.3 \pm 0.4$ & $20 \pm 1$ & $2.14 \pm 0.35$ & $18 \pm 3$ \\
\hline & $(2.00 \pm 0.44)$ & $(\mid 2.47 \pm 0.5 I)$ & $(2.04 \pm 0.18)$ & $(13.80 \pm 2.52)$ \\
\hline \multirow[t]{2}{*}{ Lung } & $1.17 \pm 0.02$ & $0.63 \pm 0.04$ & $0.10 \pm 0.03$ & $0.7 \pm 0.1$ \\
\hline & $(0.89 \pm 0.24)$ & $(3.96 \pm 1.01)$ & $(0.63 \pm 0.06)$ & $(3.04 \pm 0.52)$ \\
\hline \multirow[t]{2}{*}{ Muscle } & $0.06 \pm 0.02$ & $0.6 \pm 0.2$ & $0.02 \pm 0.01$ & $0.13 \pm 0.03$ \\
\hline & $(0.52 \pm 0.3 \mathrm{I})$ & $(2.91 \pm 0.16)$ & $(0.10 \pm 0.03)$ & $(0.58 \pm 0.27)$ \\
\hline \multirow[t]{2}{*}{ Spleen } & $0.07 \pm 0.01$ & $0.21 \pm 0.02$ & $0.03 \pm 0.01$ & $0.19 \pm 0.02$ \\
\hline & $(0.77 \pm 0.70)$ & $(2.34 \pm 0.58)$ & $(0.34 \pm 0.13)$ & $(2.11 \pm 0.35)$ \\
\hline Urine & $36 \pm 17$ & $27 \pm 6$ & $53.27 \pm 12.3$ & $38 \pm 13$ \\
\hline
\end{tabular}

\section{Conclusion}

In this study we have shown that compounds which possess some common properties as those of nitrogen containing bio-functional molecules such as oligopeptides can complex copper and increase its in vivo bioavailability. Animal studies showed that L1, L2 and L3 peptides mimics changed the bio-distribution of the copper upon both intravenous and dermal administration.

\section{Acknowledgements}

The authors thank University of Cape Town for financial support. We are also grateful to Dr JR Zeevaart and D Jansen (South African Nuclear Energy Cooperation (Ltd) for supplying us with ${ }^{64} \mathrm{CuCl}_{2}$ and J Boniaszczuk (Nuclear Medicine Dept), J Visser (Animal Unit) for technical assistance with animal experiments.

\section{Conflict of interest}

The author declares no conflict of interest.

\section{References}

1. Wang D, Miller SC, Liu XM, et al. Novel dexamethasone-HPMA copolymer conjugate and its potential application in treatment of rheumatoid arthritis. Arthritis Res Ther. 2007;9(1):R2.

2. Weyand CM. New insights into the pathogenesis of rheumatoid arthritis Rheumatology. 2000;39(Suppl 1):3-8.

3. Aeschlinmann A, Simmen BR, Michael BA, et al. (1995) Rheumatoid Arthritis. Germany: Thieme Medical Publishers; 1995. p. 8-30.

4. Wilkens RF, Gahl SL. Therapeutic Controversies in the Rheumatic Disease. USA: Grune and Stratton; 1987.

5. May PM, Williams DR. Metal Ions in Biological Systems, inorganic drugs in deficiency and disease. In: Sigel H, editor. USA: Marcel Dekker; 1981. 12:283-317.

6. Sorenson JRJ. Metal Ions in Biological Systems, inorganic drugs in deficiency and disease. In: Sigel H, editor. USA: Marcel Dekker; 1982 $14: 77-113$
7. Sorenson JRJ. Copper complexes offer a physiological approach to treatment of chronic diseases. Prog Med Chem. 1989;26:437-568.

8. Kimura E. Macrocyclic polyamines with intelligent functions. Tetrahedron. 1992;48(30):6175-6217.

9. Weder JE, Dillion TC, Hambley WT, et al. Copper complexes of nonsteroidal anti-inflammatory drugs: an opportunity yet to be realized. Coord Chem Rev. 2002;232(1-2):95-126.

10. Odisitse $\mathrm{S}$, Jackson GE. In vitro and in vivo studies of the dermally absorbed $\mathrm{Cu}$ (II) complexes of $\mathrm{N}_{5} \mathrm{O}_{2}$ donor ligands-potential anti-inflammatory drugs. Inorg Chim Acta. 2009;362(1):125-135.

11. Odisitse $\mathrm{S}$, Jackson GE. In vitro and in vivo studies of the $\mathrm{N}, \mathrm{N}$ '-bis [2(2-pyridyl)-methyl] pyridine-2, 6-pyridine-dicarboxamide-copper (II) and rheumatoid arthritis. Polyhedron. 2008;27(1):453-464

12. Nomkoko TE, Jackson GE, Nakani BS, et al. Thermodynamic and biodistribution studies of $\mathrm{Zn}(\mathrm{II}), \mathrm{Ca}(\mathrm{II}), \mathrm{Gd}(\mathrm{II})$ and $\mathrm{Cu}(\mathrm{II})$ complexes of 3,3,9,9-tetramethyl-4,8-diazaundecane-2,10-dione dioxime. Dalton Trans. 2004;5:741-749.

13. Sun $\mathrm{X}$, Wuest M, Weisman GR, et al. Radiolabeling and in vivo behavior of copper-64-labeled cross-bridged cyclam ligands. J Med Chem. 2002;45(2):469-477.

14. Packard AB, Kronauge JF, Day PJ, et al. Synthesis and biodistribution of $64 \mathrm{Cu}$-labelled monocationic diiminedioxime copper (II) complexes. Nucl Med \& Bio. 1998;25(6):531-537.

15. Jackson GE, Mkhonta-Gama L, Voyé A, et al. Design of copper-based anti-inflammatory drugs. J Inorg Biochem. 2000;79(1-4):147-152.

16. Jones-Wilson TM, Deal KA, Anderson CJ, et al. The in vivo behavior of copper 64 labelled azamacrocyclic complexes. Nucl Med \& Bio. 1998;25(6):523-530.

17. Cutler CS, Wuest M, Anderson CJ, et al. Labeling and in vivo evaluation of novel copper (II) dioxotetraazamacrocyclic complexes. $\mathrm{Nucl} \mathrm{Med}$ Biol. 2000;27(4):375-380.

18. GE Jackson, Kelly MJ. Copper anti-inflammatory drugs in rheumatoid arthritis. Part 2. A potentiometric and spectroscopic study of copper (II) polyaminodicarboxylate complexes. J Chem Soc Dalton Trans. 1989;(12):2429-2433. 